\title{
Alimentación cruda
}

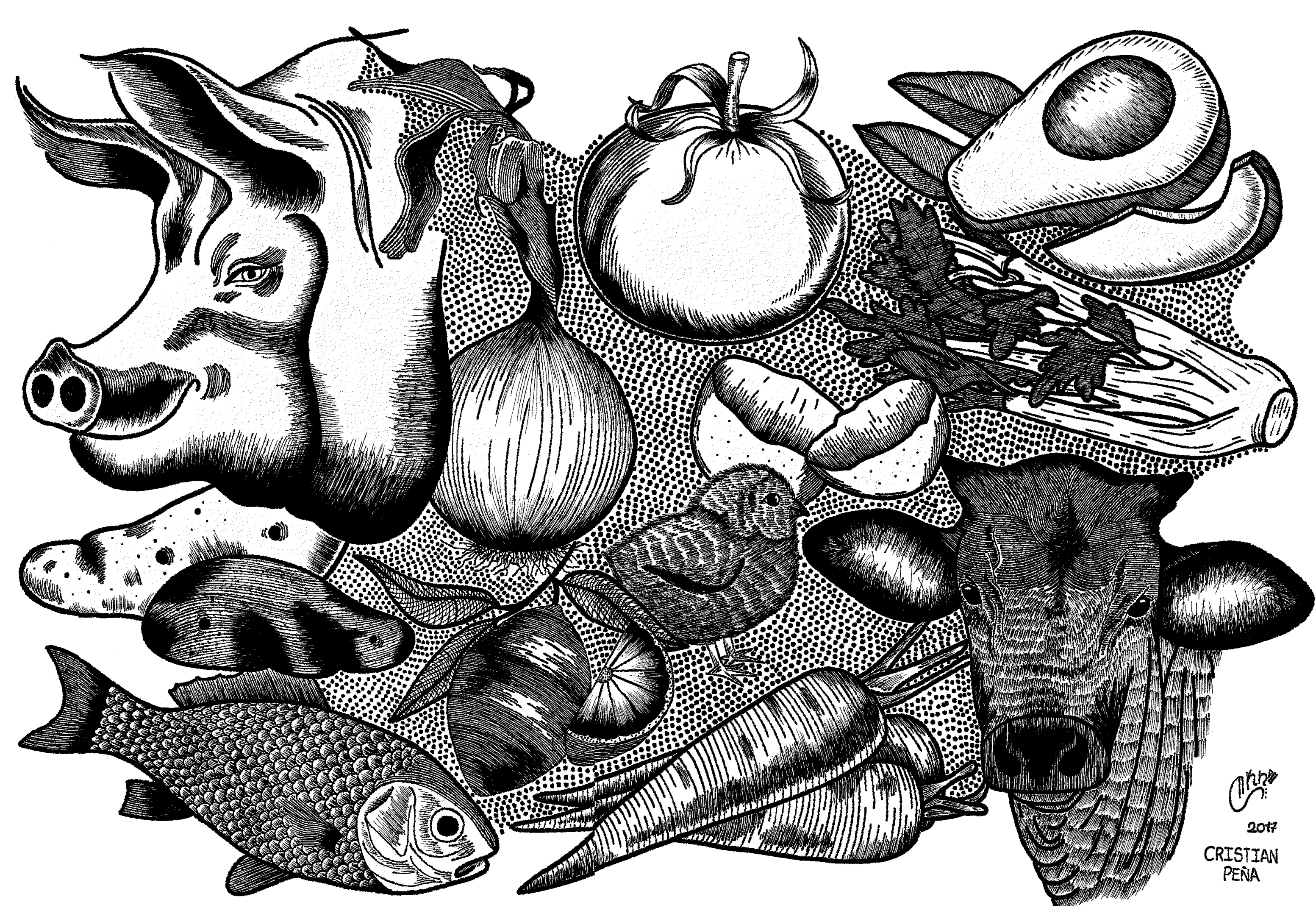

y sin censura del campo a la mesa

Por: Cristian Andrés Peña

Montaña

En esta ilustración se busca hacer una relación entre la comida y el arte, también se trata de mostrar la comida desde su estado natural, sin cocción alguna, un toro, un cerdo, un pescado, una cebolla, un tomate, entre otros, todos en su estado natural, crudos tal cual son. Esta pieza se elaboró a partir de líneas de diferentes tamaños, distancias, posiciones y grosor, algunos puntos para unificar la pieza y solamente en color negro.

La pieza busca mostrar todos estos alimentos del día a día, alimentos que consumimos comúnmente y que son de tradición y gran importancia en Colombia; se busca también crear una conciencia por la alimenación y la importancia que tienen los campesinos en ella, donde los cultivos que cuidan y la crianza de animales que realizan diariamente son parte fundamental de la alimentación colombiana e incluso, del mundo teniendo en cuenta los alimentos de gran calidad que se producen en el país y se exportan a otros lugares. 